TI 2012-073/3

Tinbergen Institute Discussion Paper
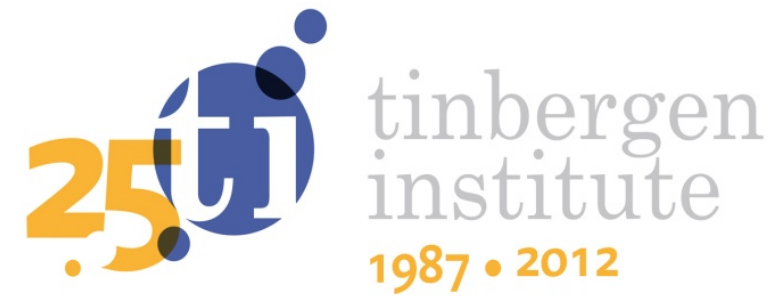

\title{
Regional Interest Rate Variations: Evidence from the Indonesian Credit Markets
}

\author{
Masagus M. Ridhwan ${ }^{a, b}$ \\ Henri L.F. de Groota,c \\ Piet Rietvelda \\ Peter Nijkampa
}

a Faculty of Economics and Business Administration, VU University Amsterdam, and Tinbergen Institute;

b Bank Indonesia, Jakarta, Indonesia;

c Ecorys NEI, Rotterdam. 
Tinbergen Institute is the graduate school and research institute in economics of Erasmus University Rotterdam, the University of Amsterdam and VU University Amsterdam.

More TI discussion papers can be downloaded at http://www.tinbergen.nl

Tinbergen Institute has two locations:

Tinbergen Institute Amsterdam

Gustav Mahlerplein 117

1082 MS Amsterdam

The Netherlands

Tel.: +31(0)205251600

Tinbergen Institute Rotterdam

Burg. Oudlaan 50

3062 PA Rotterdam

The Netherlands

Tel.: +31(0)10 4088900

Fax: $+31(0) 104089031$

Duisenberg school of finance is a collaboration of the Dutch financial sector and universities, with the ambition to support innovative research and offer top quality academic education in core areas of finance.

DSF research papers can be downloaded at: http://www.dsf.nl/

Duisenberg school of finance

Gustav Mahlerplein 117

1082 MS Amsterdam

The Netherlands

Tel.: +31(0)20 5258579 


\title{
Regional Interest Rate Variations: Evidence from the Indonesian Credit Markets
}

Masagus M. Ridhwan ${ }^{\mathrm{a}, \mathrm{b}, \mathrm{c}}$, Henri L.F. de Groot ${ }^{\mathrm{a}, \mathrm{b}, \mathrm{d}}$, Piet Rietveld ${ }^{\mathrm{a}, \mathrm{b}}$ and Peter Nijkamp ${ }^{\mathrm{a}, \mathrm{b}, *}$

${ }^{a}$ VU University Amsterdam, Department of Spatial Economics, The Netherlands

b Tinbergen Institute, Amsterdam, The Netherlands

${ }^{\mathrm{c}}$ Bank Indonesia, Jakarta, Indonesia

${ }^{\mathrm{d}}$ Ecorys NEI, Rotterdam

\begin{abstract}
This paper explores the determinants of regional differences in interest rates based on a simple theoretical model of loan pricing. The model demonstrates how risks, costs, market concentration and scale economies jointly determine the bank's interest rates. Using recent data of the Indonesian local credit markets, we find that regional interest rate variations are positive and significantly affected by the banks' risk factor, the operating costs, and market concentration. Scale economies negatively affect the interest rates. These findings help to explain geographical segmentation in loan markets.
\end{abstract}

Keywords: regional capital mobility, loan pricing, interest rates, Indonesia

JEL codes: $\quad \mathrm{R} 51, \mathrm{E} 43, \mathrm{C} 33$

\footnotetext{
* We are grateful to Adam Srihono, Riza Haryadi, Feriati Nurdinasari and Priambudi B. Darmawan from Bank Indonesia for providing the data used in this paper. We also thank Jan Möhlmann, Jos van Ommeren, Jakob de Haan, J. Paul Elhorst, and seminar participants at the Tinbergen Institute Amsterdam for their helpful comments. The usual disclaimer applies. Corresponding author: Henri L.F. de Groot, Department of Spatial Economics, VU University Amsterdam, De Boelelaan 1105, 1081 HV Amsterdam, The Netherlands. Email: h.l.f.de.groot@ vu.nl.
} 


\section{Introduction}

There are substantial income inequalities across regions which are predicted by standard theory as part of an evolutionary process in economic development. According to economic geography theories, spatial disparities may arise from several factors (see, e.g., Venables, 2010). The first is differences in the allocation of relatively immobile factors, such as natural endowments, physical geography and infrastructure availability. Second, regional disparities can also arise due to interactions between increasing returns and mobile factors of production (e.g., Krugman, 1991, Venables, 2005). This can be traced back to the classical view which emphasizes the equalization of factor prices (convergence) as a result of free trade and factor mobility (Barro et al., 1995).

This raises an important issue regarding the mobility of financial capital and its implications for regional development. National financial markets are conventionally perceived as highly integrated, but in the real world the traditional theory is no longer applicable due to imperfections in the financial markets such as asymmetric information (see Stiglitz and Weiss, 1981). Information problems potentially inhibit the mobility of (financial) capital and interregional arbitrage across regions. If local investors and financial institutions have superior information about investment opportunities in their own region, they have incentives to invest locally, and outside investors may be stuck with inferior investment opportunities, since it is costly to search for alternatives. This will possibly lead to larger regional differences in the return on capital, resulting in suboptimal allocations of capital and other resources (Greenwald et al., 1993). Furthermore, the problems of wealth distribution could be aggravated by the structure of financial services which have a tendency to concentrate in particular regions, notably a nation's core region. Financial institutions, as profit-oriented entities, seek to operate in the most efficient way. In line with the New Economic Geography (NEG) theory, financial industries are aiming to benefit from increasing returns to scale through utilizing the network externalities linked to the opportunities for grabbing tacit information (e.g., market prospects), developing new ideas (innovations), taking advantage of pooled high-quality human resources, advanced Information and Communication Technologies (ICTs), transport facilities and other related business services (see McCann, 2001; Bel and Fageda, 2008; Duranton and Puga, 2005).

Given the advantages of being spatially concentrated, banks in rich regions may create externalities at the expense of other regions. The main concerns are with their powerful centripetal forces. Banks potentially suck savings from all regions into the core region. Already 
half a century ago, Myrdal (1957) addressed the issue that (national) banks potentially siphon the savings of people in the poor regions and reinvest them in rich regions, known as 'the backwash effect'. This will lead to a disadvantageous position for peripheral regions resulting in problems in closing their funding gaps (under-investment), with adverse effects on their economic prospects. The ICT revolution in recent decades has arguably helped banks to expand their branch networks down to rural villages or into remote regions. The narrowing effective distance between regions is substantially related to the advance of technology, which is also expected to enlarge financial flows to those higher return areas, and could thus reduce national market segmentation (see, among others, Petersen and Rajan, 2002). On the other hand, one may observe a widening distribution of regional interest rates (see, for example, a survey by Dow and Rodrigues-Fuentes, 1997). In developing countries, the fragmentation of financial markets can be even more pronounced, and can result in large differences in interregional interest rates and credit availability. Not only do people in richer regions tend to have more loans, but they also pay lower loan rates compared with poorer regions. ${ }^{1}$

Concerning the existence of market imperfections, local financial institutions (notably local banks) emerge as an important solution to provide financial services to small local firms (see, for example, Pollard, 2003). By the same token, small local firms are also more likely to satisfy their financing needs at local banks than at banks with headquarters located in other regions. The literature that examines whether credit markets are spatially segmented is scarce. ${ }^{2}$ Faini et al. (1993) have shown that high loan rate differentials between banks in the northern and the southern part of Italy are mainly caused by the fact that the former banks are able to extract high monopoly rents from local firms. D'Amico et al. (1990) conclude that regional differences in Italian loan rates are mainly related to differences in GDP per capita and to the particular composition of lenders (by size and sector). A more recent study of Japanese loan markets by Kano and Tsutsui (KT) (2003) found that differentials in prefectural interest rates were due to differences in the level of prefectural GDP, the deposit rate, and market concentration (the Herfindahl Index). Although those studies have provided interesting empirical insights, they are

\footnotetext{
${ }^{1}$ Banerjee and Duflo (2010) assert that this phenomenon typically exists in developing countries, where most of the people have no access to formal credit and, alternatively, they have to rely on informal credits. In addition, they also discuss the prominent role of borrowing costs in explaining why small loan interest rates are so high; why they can vary so much across borrowers; and why the poor pay higher interest rates. Consequently, richer people borrow more and pay lower interest rates.

${ }^{2}$ Most studies on factor mobility tend to give more emphasis to labor rather than to capital mobility, as data on the mobility of labor are more readily available, especially at the regional level (Glaeser, 2005).
} 
not fully able to address all potentially relevant sources of the regional variations in interest rates. Risk and cost factors, for example, which have sound theoretical underpinnings as key variables in explaining interest rates, are broadly ignored by the KT study in particular. Here, we aim to address this shortcoming by deriving a simple analytical model of loan pricing based on bank behavior in local markets. We then obtain testable hypotheses drawn from this model, and subsequently, use econometric methods for testing the model. Another novelty of this paper is that we are - to the best of our knowledge - the first to examine a developing country, viz. Indonesia. Indonesia is an interesting case for the topics under investigation. It is widely known as a large and archipelagic country, and is also characterized by the significance of cross-regional social and economic disparities. ${ }^{3}$

This paper is organized as follows. Section 2 develops a conceptual framework and derives an empirical model to highlight differentials in regional loan rates. Section 3 contains an overview of local banking in Indonesia. Section 4 discusses the data, empirical estimation and results. Section 5 concludes.

\section{Background and theoretical framework}

\subsection{Determinants of regional variation in bank loan interest rates}

Several studies have examined whether interest rates differ across regions within a country, and what factors can explain their differences (for example, Aspinwall, 1970; D'Amico et al., 1990; McKillop and Hutchinson, 1990; Faini et al., 1993; Kano and Tsutsui, 2003). These studies find convincing evidence for regional interest rate differentials and conclude that credit markets are geographically segmented. In addition, these studies also find that regional variations in loan rates are primarily due to differences in market concentration, risk factors, operating costs, loan size, costs of funds, and region-specific factors (e.g., Rodriguez-Fuentes, 2005). Using these studies as point of departure, we discuss several key factors that may determine regional interest

\footnotetext{
${ }^{3}$ Indonesia is one of the most diverse countries in the world, with living standards that range from developed country standards to entrenched poverty. Per capita regional product (GRP) in the richest province, East Kalimantan, was around 13 times larger than in the poorest, Maluku. Poverty rates range from less than three percent in some cities (Denpasar, Bali; Bekasi, West Java) to more than 50 per cent in Manokwari, Papua (World Bank, 2007). These economic disparities reflect differences in natural resource endowments, institutions, geography, and ethnicity, among other things.
} 
rate differentials in Indonesia, and employ them as explanatory variables in our regional interest rate models.

Deposit rate - The deposit rate is important in determining loan rates as it represents the basis for the cost of funds. As an intermediary agent, banks basically engage in disbursing credits for the demanders (borrowers). To do so, they need to collect funds from sources (mainly households and firms). In return, banks will pay interest for the deposited money to their depositors. In Indonesia, to protect funds from bank failures, the government has provided a blanket-guarantee saving scheme. The government regularly announces the guaranteed (insured) rate for the savings. This policy measure is considered vital to restore confidence in domestic banks in the aftermath of the 1997-98 crisis, especially for rural banks which are perceived to be riskier than national banks. To attract more savings, they tend to offer high saving rates that are close to the guaranteed maximum rate.

Risk - Financial markets are plagued by asymmetric information. Banks as one of several financial intermediary agents are often considered to be in a better position to address such market imperfections. Information problems are commonly present in the form of moral hazard and adverse selection (cf. Stiglitz and Weiss, 1981; Diamond, 1984). Given the information problem between banks and borrowers, firm size may also affect bank's perceptions of risk. National (transactional) banks operating in local credit markets would commonly meet small businesses (SMEs) as their extended customers. Small businesses are characterized by their massive numbers and tiny scales, have volatile earnings and are highly reliant on banks as external financing sources. Also, their characteristics are typically associated with the informational opacity of their operational and financial conditions. Banks therefore tend to regard small businesses as (potential) risky borrowers resulting in either no provision of capital or provision at a relatively high interest rate. Meanwhile, banks operating in local markets (relationship banks) may gain informational advantages owing to their proximity to local borrowers. Jimenez et al. (2009) who have studied the Spanish small loan markets, assert that a close bank-borrower relationship increases the bank's willingness to take risk. Furthermore, several studies indicate that the information problem may also increase with physical distance. A model developed by Hauswald and Marquez (2006) shows that the precision of the signal about a 
borrower's quality received by a bank increases with geographical proximity. Consequently, banks' perceptions on risk may increase as the proximity between bank (lender) and borrower increases. In turn, if regions differ with regard to their proximity, so does the risk.

Operating Costs - As pointed out by Berger and Udell (1995) and Petersen and Rajan (1994), in dealing with small-scale borrowers, lenders lack the 'hard' information provided by financial statements that are typically available for large firms. Thus, they have to rely on 'soft' information which is informally collected through relationship lending between the lender and the borrower. The collection of this soft information is costly, as it may require multiple site visits by a loan officer to their borrowers' sites (for monitoring purposes), and more importantly, specialized knowledge of the local market in which the firm operates. Besides the monitoring costs, banks may also incur another type of costs before a loan is granted: namely, screening costs. During pre-credit assessments, various types of information need to be scrutinized by loan officers such as finding out the borrower's residence, his occupation, his wealth, and also his personal character. Assessing the creditworthiness of a potential borrower is indeed costly for banks. In addition, Banerjee and Duflo (2010) argue that high interest rates for small loans are mainly related to the high fixed costs of administering a loan (monitoring, screening, collection, etc.). Such high costs can further explain why interest rate differentials are so apparent across borrowers, and why the poor pay higher interest rates. Meanwhile, local banks operating in local markets could have informational advantages, and hence it would be less costly for them to do the monitoring activities than national (commercial) banks that operate at a distance (see, for example, Berger et al., 2002).

Economies of scale - The former discussion highlights the presence of information asymmetries in credit markets which lead to high transaction costs. The latter problem may even be more pronounced when dealing with small-sized loans. A simple solution to the problem is to bundle the massive and tiny credits together, so that banks can exploit the advantage of economies of scale. As the volume of loans increases, transaction costs per unit of the granted loans go down. Early studies in this area have been undertaken by Benston $(1965,1972)$ and Bell and Murphy (1968). They found that the US banks that increase in size experience a significant reduction in the average costs of their lending. Nevertheless, Berger and Humphrey (1997) emphasized that 
scale economies are relevant only for smaller US banks, while for the largest banks either the average costs are constant or diseconomies of scale prevail. A study of Japanese cooperative banks by Deelchand and Padgett (2009) also supports that only small banks can apparently reap the advantage of scale economies, while the larger banks cannot. ${ }^{4}$ In contrast, several studies in Europe found significant importance of scale economies in its banking industry (see, e.g., Simper, 1999; and Altunbaş et al., 2001).

Market concentration - Sparse regions may be portrayed with a relatively high incidence of small-sized businesses compared with dense regions (e.g., owing to the presence in the latter of multinational corporations/MNCs). In terms of funding sources, the small businesses are typically more dependent on local bank finance, or have less access to external finance, than the bigger ones (Berger et al., 2005; Uchida et al., 2008). Moreover, in a region with more concentrated markets (less competition), banks tend to exert their power by charging higher interest rates, and possibly rationing their credits. Petersen and Rajan (1995) have shown that the spatial distribution of banks in the local market may lead to an increase of the banks' market power. The smaller physical distance between banks and borrowers may be to the advantage of local (relationship) banks that are better at exploiting soft information (personal communication) than national (transactional) banks that operate at a distance. Acquiring opaque information is necessary for banks in evaluating how to grant their credits effectively. Even though national banks can rely on more sophisticated technology (ICTs), face-to-face contact is undoubtedly still necessary, both in the ex-ante and ex-post period of the credit disbursements. Therefore, local (relationship) banks that are located in proximity to their borrowers tend to maintain a higher degree of market power, and hence, extract monopoly rents, relative to the competing banks (see Degryse and Ongena, 2005). Generally speaking, the concentration of banks in the local geographical market may then also reflect the strength of banks' market power (see also Petersen and Rajan, 2002; Black and Strathan, 2002; Corvoisier and Gropp, 2002).

\footnotetext{
${ }^{4}$ To what extent economies of scope exist is still an open empirical question in view of the mixed evidence that is found especially for the large banks. One possible explanation is given by Berger and Humphrey (1997), who argue that the mixed findings are caused by the econometric difficulties in identifying cost functions for financial conglomerates. For small banks, it may be their size that allows them to achieve increasing returns to scale. Further discussion of this issue is beyond the scope of this paper.
} 


\subsection{A simple model of loan pricing}

On the basis of the previous review of key determinants of regional variation in interest rates, we now turn to a simple model of bank behavior in a local market, which is adapted from Corvoisier and Gropp (2002), Freixas and Rochet (2008), and Barajas et al. (1999). The model aims to provide a framework for the empirical analysis that is to follow. We begin by simply assuming that there are $P$ banks that only operate in a region $q$. They offer only one type of liability product, namely deposits $\left(D_{p}\right)$ and provide one type of loan to their customers $\left(L_{p}\right)$. We can then write the operational bank system as follows:

$$
L_{p}+R_{p}=D_{p}
$$

where $R_{p}$ represents the amount of reserves that is required by the central bank to be held, and assumed to be proportional to the amount of deposits $\left(D_{p}\right): R_{p}=\varphi D_{p}$. Given the required reserve ratio $(\varphi)$, the simple balance condition that should be fulfilled for each bank is:

$$
L_{p}-D_{p}(1-\varphi)=0 \text {. }
$$

Banks typically receive income from the granted loans $\left(r_{q}{ }^{L} L_{p}\right)$ and pay interest on the deposits $\left(r_{q}^{D} D_{p}\right)$. The interest rates are assumed to be region-specific and the same for all banks within the region. In addition, banks incur input costs $(C)$, which are primarily affected by the scale of their operations $(L)$ and administrative and operating costs $(O C)$. Given the probability of bank loan defaults $\left(\sigma_{q}\right)$, banks optimally chose the amount of loans granted, where the regional interest rate is a function of the total amount of loans granted in the region: $r_{q}=f\left(L_{q}\right)$ where $L_{q}=\Sigma L_{p}$. The individual banks' objective function in maximizing its profits equals:

$$
\max \Pi_{p}=\left(1-\sigma_{q}\right) r_{q}^{L} L_{p}-r_{q}^{D} D_{p}-C\left(L_{p}, O C\right) .
$$

Then, differentiating (3) with respect to $L_{p}$ gives the first-order condition:

$$
\partial \Pi_{p} / \partial L_{p}=\left(1-\sigma_{q}\right) r_{q}{ }^{L}+\left(1-\sigma_{q}\right) L_{p} \partial r_{q}{ }^{L} / \partial L_{p}-r_{q}{ }^{D} \partial D_{p} / \partial L_{p}-D_{p} \partial r_{q}{ }^{D} / \partial L_{p}-\partial C / \partial L_{p}=0 .
$$

Recall that according to condition (2), the growth of credit is restricted by the amount of reserves the banks must maintain, so $\partial D_{p} / \partial L_{p}=1 /(1-\varphi)$. We define $M_{L}$ and $M_{D}$ which are related to the interest rate elasticity of loans as follows:

$$
\begin{aligned}
& M_{L}=1+\left(\partial r_{q}{ }^{L} / \partial L_{p}\right) \cdot\left(L_{p} / r_{q}{ }^{L}\right)=1+\left(\partial r_{q}{ }^{L} / \partial L\right) \cdot\left(L / r_{q}{ }^{L}\right) \cdot\left(\partial L / \partial L_{p}\right) \cdot\left(L_{p} / L\right), \text { and } \\
& M_{D}=1+\left(\partial r_{q}{ }^{D} / \partial D\right) \cdot\left(D / r_{q}{ }^{D}\right) \cdot\left(\partial D / \partial D_{p}\right) \cdot\left(D_{p} / D\right) .
\end{aligned}
$$


Equation (4) can then be rewritten as follows:

$$
\left(1-\sigma_{q}\right) \cdot r_{q}{ }^{L} \cdot M_{L}=r_{q}^{D} \cdot M_{D} /(1-\varphi)+\partial C / \partial L_{p} \text { so } r_{q}{ }^{L}=\left[r_{q}^{D} \cdot M_{D} /(1-\varphi)+\partial C / \partial L_{p}\right] /\left[\left(1-\sigma_{q}\right) M_{L}\right] .
$$

Both $M_{D}$ and $M_{L}$ can be argued to be related to the market concentration. For estimation purposes, we will assume these two to be strongly correlated and will in the sequel - without loss of generality - replace them by a general indicator for market concentration $M$. Furthermore, we assume the marginal input costs to be a function of the volume of loans $(L)$ and the operating costs $(O C)$. Then we arrive at the following expression for $r_{q}{ }^{L}$ :

$$
r_{q}^{L}=f\left(r_{q}^{D}, \varphi, \sigma_{q}, L_{q}, O C_{q}, M_{q}\right)
$$

So the lending rate $r_{q}{ }^{L}$ is affected by the effective borrowing rate $r_{q}{ }^{D}$ (after adjusting for the national reserve ratio), the market concentration $\left(M_{q}\right)$, the operating (administrative) cost $\left(O C_{q}\right)$ of the banks in $q$, the average loan volume of the banks in $q\left(L_{q}\right)$ and the probability of loan defaults $\left(\sigma_{q}\right)$. This equation forms the basis for our empirical analysis in Section 4. But before turning to the empirical analysis, we first provide an overview of the local banking markets in Indonesia to give the context that is needed to interpret the empirical results.

\section{Local banking markets in Indonesia: An overview}

In Indonesia, local financial institutions are largely present either as People's Credit Banks (Bank Perkreditan Rakyat, or BPRs) or Regional Development Banks (Bank Pembangunan Daerah, or BPDs). ${ }^{5}$ While the commercial (national) banks have an extensive branch network throughout the country, the two types of local banks are restricted in running their businesses, including being allowed to open branches only in the same province as where their headquarters are located.

BPRs are commonly called 'rural banks' (bank desa) because of their locations in rural areas. Although some BPRs have attempted to expand their operations towards urban or peri-urban areas, their movements are to a great extent handicapped by strong competition with commercial banks, and a location-based capital regulation imposed by the Financial Authority (Bank Indonesia). In 2008, there were 1,772 BPRs with 3,367 branches operating in the country (including Village Credit Boards, BKDs).

\footnotetext{
${ }^{5}$ In addition, small (rural) financial institutions may also be present in the same regional area, such as Saving and Loan Cooperatives; Pawnshops; Rural Village Credit Institutions (Lembaga Dana Kredit Pedesaan / LDKPs), not to mention Shariah-based banking and Baitul Mal wat Tamwil (BMTs).
} 
Local banks like BPRs are widely known to have a substantial role especially in providing local financial services for small local firms. These firms typically have a tiny size, yet they are an important component in the national economy. As a relatively simple form of banking institution, BPRs are regulated differently than commercial banks. They cannot borrow either from capital markets or from overseas. ${ }^{6}$ With such binding regulations, BPRs only have limited funding sources, and thereby, to a great extent, they are highly dependent on people's savings and the owner's capital. Thus, bank loan portfolios are subject to the amount of local funding available. $^{7}$

BPRs have a rather low reputation that originates in part as a result of several occurrences of bank failure. The public tends to perceive that saving money in those banks is more risky than in the commercial (national) banks. The former face stiff competition from the latter (being supported by advanced technology and a better reputation). As a consequence, to attract more savings, local banks have to offer high interest rates for their products. Nevertheless, the offered rate should not be excessive, and commonly it is at par with the rate guaranteed by The Indonesian Deposit Insurance Corporation (Lembaga Penjaminan Simpanan, or LPS). Beyond the threshold rate, depositors will not get refunds from the LPS in case their bank goes bankrupt. Having been anchored to the reference rate, bank savers would be best advised to put their money in BPRs, while at the same time enjoying higher saving rates compared with the commercial banks' rates. This is supported by the data we obtained from Bank Indonesia (BI), which show the BPRs' loan rates vary widely across regions, while deposit rates are predominantly spatially invariant.

Another variant of local banks refers to Bank Pembangunan Daerah (BPD) which is literally translated as 'regional development banks', or simply regional banks. Although they can be literally translated as a development bank, judging BPDs from their lending activities in particular may be misleading. This is mainly because most of the BPDs' credits are directed to retail (consumer) markets rather than to financing public infrastructures or other local government projects, which is typically known as a core function of development banks. Interestingly, Indonesia's regional development banks have a 'niche' market segment: namely,

\footnotetext{
${ }^{6}$ By regulation, BPRs are considered as formal financial institutions, but if we observe their operational characteristics more carefully, we may also consider them as informal institutions.

7 As an alternative remedy for this problem, recently BPRs have been allowed to participate in a 'linkage programme' that has been initiated by the government to link between commercial banks, which notably have a surplus of funds and a lack of credits, and BPRs which have a shortage of funds (see Sunarto, 2007).
} 
local government employees (Pegawai Negeri Sipil, or PNS). ${ }^{8}$ Since BPDs are owned by the local authorities, civil servants automatically become their customers, where the banks maintain their payroll accounts and employees' loans, which account for about 80 per cent in total portfolio credits. Most money is used for consumer credits. However, the recent growing trends of micro-finance business in Indonesia, have also encouraged them to be more strongly involved in the small business loan markets. Total market share of their loans is around 9 percent of the national total.

As local-based banks, the headquarters of BPDs are usually located in the capital city of the province and have branches throughout. Even though - by regulation - they do not face a strict branch restriction like BPRs, considering their high dependence on local stakeholders, they may not wish to expand their businesses in other provinces. With such (quasi-) monopoly power in their hands, this, in turn may also discourage BPDs from competing with other banks in other provinces. $^{9}$

In 2008, there were 26 BPDs with 1,310 branches operating throughout the country, or one in each province. The major source of the BPDs' funding is current accounts with cheques (about 60 per cent) which are basically short-term funds on account of their high turnovers. In order to manage their liquidity demand especially for long-term funds, the banks are mostly reliant upon their local shareholders, and offer high interest rates to their savers. ${ }^{10}$

The conventional view is that collateral is a binding prerequisite before banks decide to grant credits (Bester, 1987). In practice, small bank operations are widely based on "relationship lending" and this also holds for Indonesia (Cole et al., 2004). As a consequence, creditworthiness tends to be the first consideration rather than a physical collateral. Johnston and Morduch (2008), using the results of Microfinance Access and Services Survey (MASS) conducted in Indonesia, indicate that only 10 per cent of households in their sample who are creditworthy, consider lack of collateral to be a deterrent for credits. A survey by World Bank in Indonesia (2009) also concludes that lack of collateral does not seem to be a generalized problem for small-size loans.

\footnotetext{
${ }^{8}$ In addition, BPDs have a special function as a cash manager (bookkeeper) which manage local administrative budgets and facilitates payment of transactions for local projects.

${ }^{9}$ In the most recent period, a few BPDs have started to open branches in Jakarta, with the primary aim of managing their internal liquidities (interbank markets), and facilitating local authorities financial activities specifically in relation to decentralization funds from central government.

${ }^{10}$ It is widely known that some BPDs sporadically also extend extra bonuses to top rank government officials (prime sources of the banks' funding sources), and thus, the graft is basically aimed to maintain their 'loyalities' to the banks (visit: http://www.infobanknews.com/).
} 
The principle of lending against income, not collateral, however, may already be well-understood by banks especially in dealing with small-scale credits. The government has also become actively engaged in promoting this principle in order to spur bank lending, especially for small firms, as is laid down in the Bank Act number 10/1998.

From the above explanations, it can be clearly seen that, although BPRs and BPDs are both functioning as local banks, their markets are segmented. This is clearly illustrated in Figures 1 and 2 which depict the regional variation in loan rates of both types of local banks indicating clear spatial segmentation. ${ }^{11}$ The two figures show that the Eastern part of Indonesia (Maluku and Papua), Bengkulu in Sumatra, and some provinces in Sulawesi are the regions with the highest loan rates relative to the rest of the regions. The regional loan rates are measured as the weighted average of the interest incomes of individual banks based on the volume of loans in 26 provinces during the period 2000-2008. The interest rate data are market-based, free from subsidized credit rates and /or bank credits based on the Shariah principle.

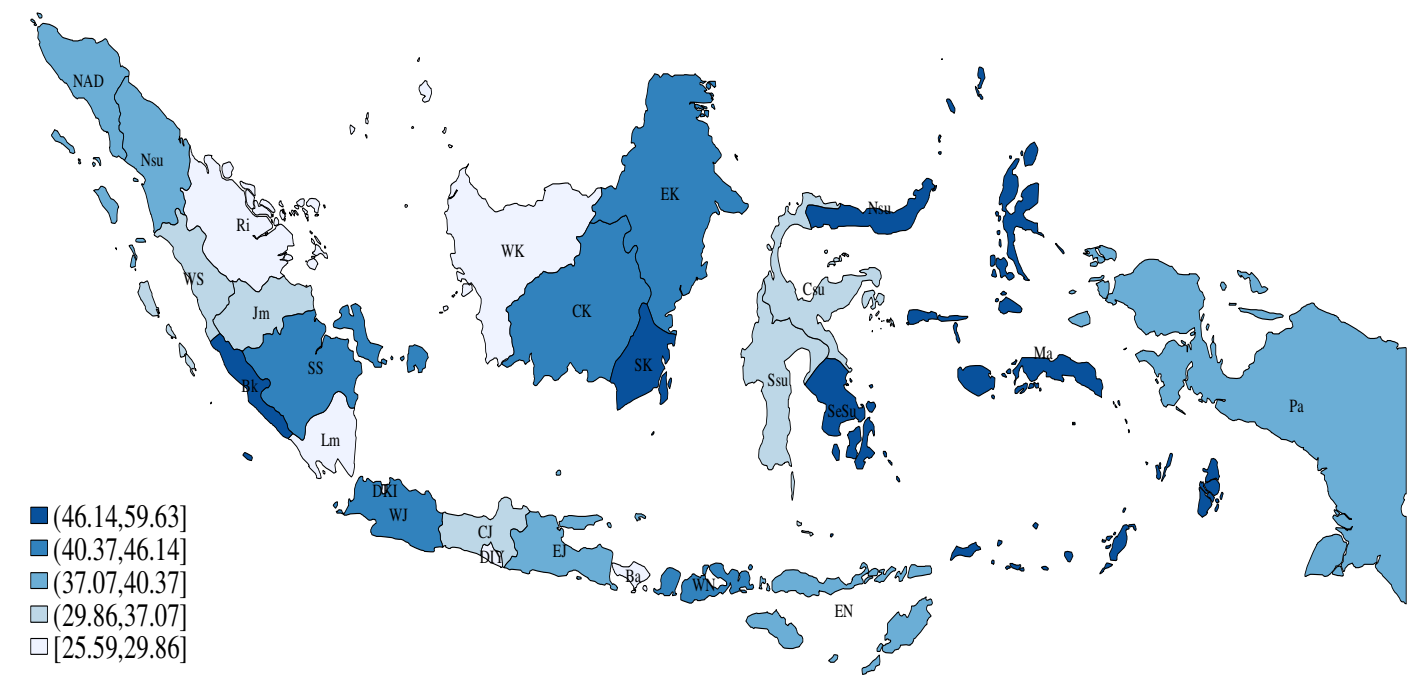

Figure 1: Regional differences in rural bank loan interest rates

(in percent per year, average of 2000-2008) ${ }^{12}$

\footnotetext{
${ }^{11}$ A simple regression of loan rates on dummy variables representing the provinces indicates that the regional dummies are jointly significant.

12 Indonesian provinces consist of DI Aceh (NAD), North Sumatera (NS), Riau (Ri), West Sumatera (WS), Jambi (Jb), Bengkulu (Bk), South Sumatra (SS), Lampung (Lp), DKI Jakarta (DKI), West Java (WJ), Central Java (CJ), DI Yogyakarta (DIY), East Java (EJ), Bali (Ba), West Kalimantan (WK),South Kalimantan (SK), Central Kalimantan (CK), East Kalimantan (EK), South Sulawesi (SSu), Central Sulawesi (CSu), Southeast Sulawesi (SeS), North Sulawesi (NS), West Nusa Tenggara (WN), East Nusa Tenggara (EN), Maluku (Mk) and Papua (Pa).
} 


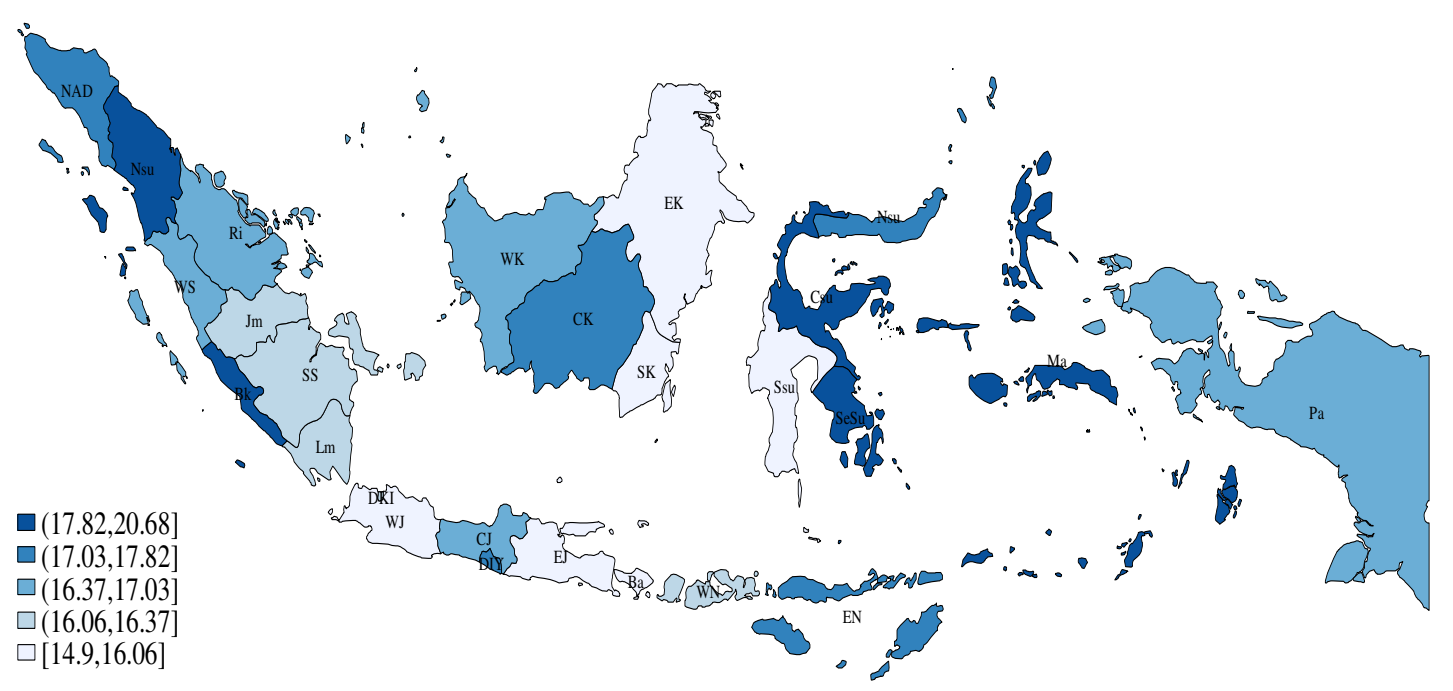

Figure 2: Regional differences in regional bank loan interest rates

(in percent per year, average of 2000-2008)

\section{Empirical Analysis}

\subsection{Model specification and descriptive statistics}

After the presentation of our conceptual and analytical framework (Section 2) and discussion of the characteristics of (regional) financial markets in Indonesia (Section 3), we now turn to the empirical analysis that is at the heart of this paper in which we try to detect the sources of regional variation in loan rates presented in Figures 1 and 2. Referring back to the key equation (5) that we derived in Section 2, it is important to realize that we may ignore the deposit rate in our estimation given its lack of regional variation. Similarly, we can also drop the reserve requirement measure $(\varphi)$, which is known as a monetary policy instrument, and thus is uniformly imposed throughout the country. We can then specify a reduced-form model of loan pricing at the regional level that can be used as a workhorse for our empirical analysis:

$$
R A T E=\beta_{0}+\beta_{1} R I S K+\beta_{2} C O S T+\beta_{3} S C A L E+\beta_{4} \text { CONCENTRATION }+u_{i t} .
$$

The bank loan interest rate (RATE) for the two respective types of banks is our dependent variable in the two models that we are going to estimate (see Figure 1 and 2). As shown in Table 1 , the average interest rate of rural banks is $38.2 \%$ which is much higher compared to the rate of regional banks by $16.9 \%$. In addition, the largest proportion of credits disbursed by rural banks are notably in the form of trade credits for micro- and small firms (micro-credit), while, most of 
the regional banks' credits are granted for consumer spending and for local government employees. Furthermore, the correlation coefficient between the interest rate of rural banks and regional banks is found to be only 0.21 . This is an early indication that the loan markets between the two banks are segmented.

RISK serves as proxy for $\sigma_{q}$. Credit risk is difficult to measure especially when dealing with small businesses (in rural areas). Therefore, we have to resort to the most common measure of risk used by pertinent studies in credit markets, viz. the share of problem (non-performing) loans in total bank loans (for example, Faini et al., 1993; Corvoisier and Gropp, 2002). ${ }^{13}$ In the lender's view, this measure is the best that can be observed. As long as borrowers pay their credits when they are due, banks should consider them as less risky (performing), and vice versa. Thus, this measure may simply reflect the reputation of borrowers.

COST is measured as the ratio of total labor expenses incurred by banks to the total income generated. This proxy primarily aims to capture the administrative costs incurred by banks, particularly those related to their lending activities.

To control for differences in the scale of operations $(L)$, we use the ratio of total credits with respect to the number of banks (SCALE) as its proxy. The scale variable is in real terms, and is calculated as the total amount of credits deflated by the Consumer Price Index (CPI) with 2002 as the base year. ${ }^{14}$

CONCENTRATION (market concentration) serves as a proxy for $M$ in our model and is based on available data; it is simply measured by the Herfindahl index (HI). Several relevant studies have also applied this index to measure the market concentration of local banks (e.g., Petersen and Rajan, 2002; Black and Strathan, 2002; Corvoisier and Gropp, 2002; Maudos and De Guevara, 2004). ${ }^{15}$ The index for each local market is defined as the sum of squared market shares, where market shares are based on branch-level outstanding loans of banks in the province. It can vary between zero and one. The average $\mathrm{HI}$ index is 0.21 (see Table 1), which suggests that

\footnotetext{
${ }^{13}$ A loan is nonperforming when payments of interest and principal are overdue by 3 months or more. We use data on gross non performing loans (NPL) so non performing loans exclude provisions for losses made by the banks. Lack of data on loss provision prevent us from using net NPL as an alternative.

${ }^{14}$ The CPI inflation is the most readily available data at the regional level, while other types of price deflators were not available within the time period of this study.

${ }^{15}$ According to Bikker and Haaf (2002a), employing the concentration measure as a measure of bank competition gives rise to misleading inferences and measurement problems especially when the number of banks is small (see also Bikker and Haaf, 2002b). Instead, they recommend employing Lerner Indices to measure the degree of monopoly power. However, lack of data on marginal costs prevent us from employing the latter measure.
} 
credit markets are relatively strongly concentrated (see also World Bank, 2009). In each province, there is only one regional bank (BPD) operating, so we dropped this variable.

The data used in this study have been made available by the Central Bank of Republic of Indonesia (Bank Indonesia, or BI). As stated in BI regulation, all banks operating throughout the country are obliged to report their daily financial activities through both an online and an offline (paper-based report) system in time, real and accurately. ${ }^{16}$ When they fail to comply with this regulation, banks can be sanctioned by certain penalties depending on the degree of their noncompliance.

Table 1: Descriptive statistics for rural and regional banks

\begin{tabular}{clccc}
\hline \multicolumn{1}{c}{ Bank } & \multicolumn{1}{c}{ Variable } & Mean & Median & St. dev. \\
\hline Rural Bank (BPR) & RATE (\%) & 38.60 & 38.20 & 9.58 \\
& RISK (\%) & 10.54 & 9.18 & 5.31 \\
& COST (\%) & 14.36 & 11.49 & 10.12 \\
& SCALE (in millions of rupiahs) & 65.17 & 40.00 & 78.12 \\
& CONCENTRATION (index) & 0.21 & 0.20 & 0.08 \\
Regional Bank (BPD) & RATE (\%) & 16.98 & 16.93 & 2.82 \\
& RISK (\%) & 13.24 & 11.42 & 8.54 \\
& COST (\%) & 28.53 & 24.77 & 12.14 \\
& SCALE (in millions of rupiahs) & 95.47 & 95.28 & 8.80 \\
\hline
\end{tabular}

Note: Figures are not directly comparable between rural and regional banks.

\subsection{Estimation results}

We begin by presenting the results of the regional bank interest rate model specified in equation (8) based on the pooled annual data of 26 regions for the period 2000-2008. We employ a panel data approach. The main attraction of the approach is the possibility of consistent estimation controlling for unobserved regional and /or temporal heterogeneity that might otherwise bias the results. This is done by further specifying a one- or two-way error component model (e.g., Baltagi, 2005) in which we estimate region- and /or time-specific fixed effects. These fixed effects absorb the specific effects of regions or years and as such control for potentially relevant

\footnotetext{
${ }^{16}$ See Bank Indonesia Regulation number 7/7/DPM dated 29 March 2005, among others.
} 
spatial or temporal unobserved heterogeneity. A standard Hausman test confirms the appropriateness of using the fixed effects model.

Our main results for the rural banks loan rates are shown in Table 2. Specification (1) shows the results of a pooled OLS analysis. Under the classical assumption that the error process is independently and identically distributed and is correctly specified, the model can be consistently estimated using Ordinary Least Squares (OLS). All the estimated coefficients have the expected sign, and most of them are also statistically different from zero. Specifications (2)-(4) present the results with the inclusion of spatial and temporal fixed effects. Finally, specification (5) presents the results in first differences.

Table 2: Estimation results of rural bank loan interest rates ${ }^{a}$

\begin{tabular}{lccccc}
\hline \multirow{2}{*}{ Explanatory Variables } & $\begin{array}{c}\text { Basic } \\
(\mathrm{OLS})\end{array}$ & Fixed Effects & Fixed Effects & Fixed Effects & $\begin{array}{c}\text { OLS-First } \\
\text { Differencing }\end{array}$ \\
\cline { 2 - 6 } & $(1)$ & $(2)$ & $(3)$ & $(4)$ & $(5)$ \\
\hline RISK & $0.426^{* * *}$ & 0.046 & $0.457^{* * * *}$ & 0.027 & $0.067^{*}$ \\
COST & $(0.10)$ & $(0.07)$ & $(0.11)$ & $(0.06)$ & $(0.04)$ \\
& 0.020 & $0.147^{* * *}$ & 0.023 & $0.135^{*}$ & $0.107^{* * *}$ \\
SCALE & $(0.05)$ & $(0.04)$ & $(0.07)$ & $(0.08)$ & $(0.04)$ \\
& $-0.040^{* * *}$ & $-0.200^{* * *}$ & $-0.037^{* * *}$ & -0.005 & $-0.538^{* * *}$ \\
CONCENTRATION & $(0.01)$ & $(0.01)$ & $(0.01)$ & $(0.01)$ & $(0.16)$ \\
& $14.308^{* *}$ & $12.641^{* * *}$ & $12.468^{* *}$ & 0.891 & $13.462^{* * *}$ \\
INTERCEPT & $(6.03)$ & $(4.32)$ & $(6.49)$ & $(4.57)$ & $(3.61)$ \\
& $33.486^{* * * *}$ & $34.656^{* * *}$ & $31.547^{* * *}$ & $33.307^{* * *}$ & $6.583^{* * * *}$ \\
REGION DUMMIES & $(2.01)$ & $(1.54)$ & $(2.23)$ & $(1.52)$ & $(1.36)$ \\
TIME DUMMIES & no & yes & no & yes & no \\
\hline Observations & no & no & yes & yes & yes \\
Adjusted $R^{2}$ & 234 & 234 & 234 & 234 & 208 \\
\hline
\end{tabular}

Notes: Robust (White heteroscedasticity-consistent) standard errors in parentheses. ${ }^{*}$ means statistically significant at the $10 \%$ level; ${ }^{* *}$ at the $5 \%$ level; and ${ }^{* * *}$ at the $1 \%$ level.

An advantage of the fixed effects models is that we obtain estimated coefficients for the region dummies. These are of interest in that they reveal the importance of location specific factors that 
are not captured by our explanatory variables and / or common trends in the data that may bias our results. Generally the estimated fixed effects are jointly and individually statistically significant at the $1 \%$ level. For brevity, we do not report them in the Table, but instead we plot the coefficients to illustrate the spatial variation (see Figure 3). Lagging and remote regions (with minimum infrastructure facilities), particularly Maluku and Bengkulu, show the largest effects. These results may well point at the relevance of their specific location or remoteness. For Maluku, it is important to notice that it has experienced long-standing civil conflicts, which had significant negative impacts on the region's economic performance. The large fixed effect for Bengkulu might be caused by the perception that it is more prone to natural shocks.

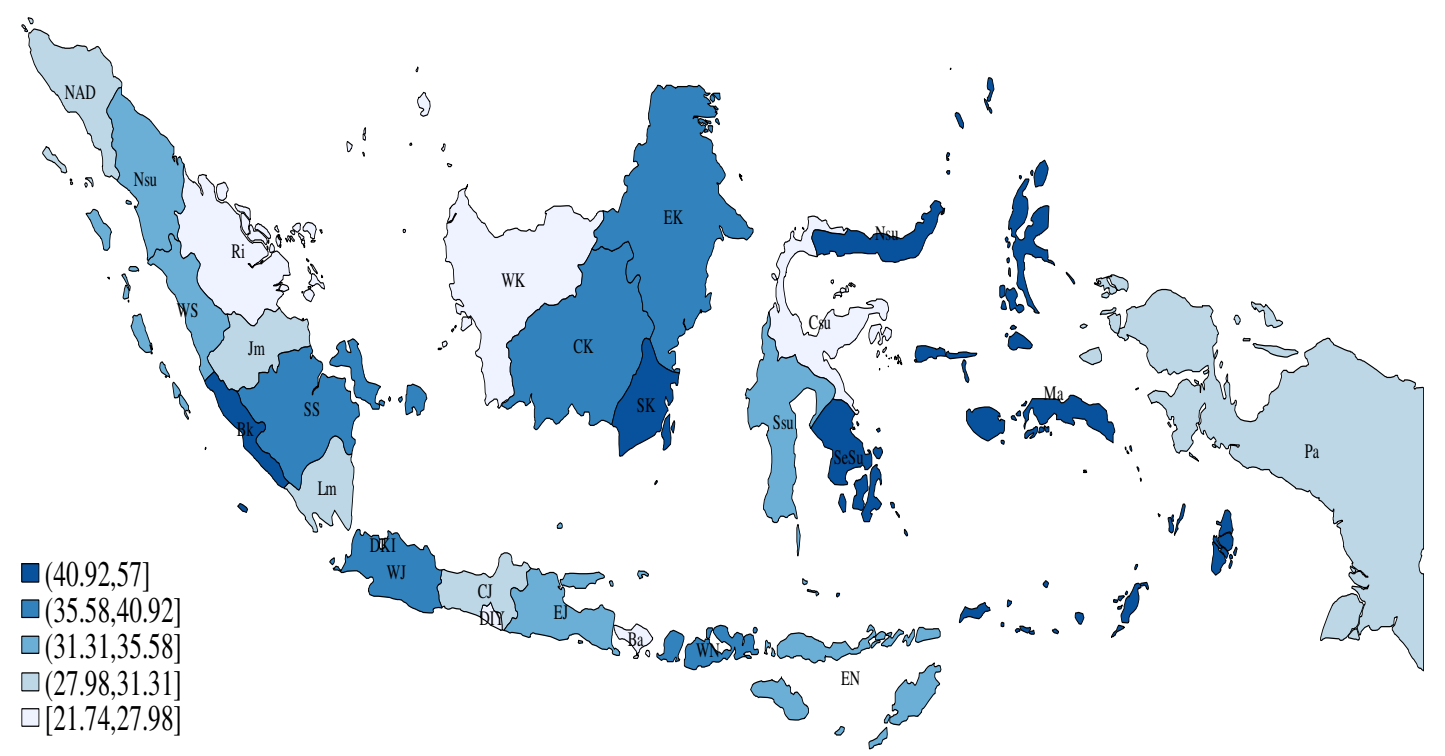

Figure 3: The estimated coefficients of region dummies from the rural bank regression.

Specification (3) is estimated by allowing for time-fixed effects which is particularly relevant since we are dealing with financial time series data. The rural bank interest rate may potentially shift over time because of, for example, inflationary effects. Time fixed effects will then absorb cross-regional co-movement over time. Their estimates represent average cross-sectional effects, and take into account shifts over time in the position of the regions relative to each other (between regions). Also in specification (3), most of the coefficients are statistically significant and with the expected sign. It appears that the variation of rural bank's interest rates across 
regions are broadly explained by variation in risk, scale, and concentration. Meanwhile, costs turn out to be statistically non-significant. This illustrates that costs develop more or less similarly in all the regions over time, and the effect is therefore captured by the time-specific effects.

The two-way effects model allows intercepts to vary across regions and over time (year). In the standard literature, these effects basically estimate a 'pure' effect of the model, as all unobserved heterogeneity (region- and year-specific) is absorbed by the dummy variables. In Column (4), even though most of the variables are non-significant (except for cost), all coefficients of region and year dummies are statistically significant. This result suggests that the variation in interest rates across regions and over time is largely picked up by region- and timespecific fixed effects. As evidenced by the comparison of the adjusted $R^{2}$-values in the first four specifications, the importance of spatial variation far outweighs the importance of temporal variation.

Finally, we turn to specification (5). The previous specifications have not fully addressed the possibility that error terms are serially correlated over individual observations (biasing the standard errors). On the basis of a serial correlation test developed by Wooldridge (2002) in panel-data models, we cannot reject the null hypothesis that there is first-order serial correlation in our data. A straightforward solution for this problem is to apply the First-Differencing method, which estimates the association between individual-specific one-period changes in the explanatory variables and individual-specific one-period changes in the dependent variable. Accordingly, it also corrects for bias due to correlation between the explanatory variables and the error term. Unlike specifications (2) and (4), the first-differences model removes individual specific effects. Following Wooldridge (2002), to capture the aggregate time effects, we add a time dummy variable in the specification. The results show that all explanatory variables are statistically significant and have the expected sign.

Following a similar approach, we now report regression results for regional banks (BPDs) in Table 3. The discussion is kept brief. We find that the signs of the coefficients are similar compared with the rural bank regression, while statistical significance of explanatory variables is substantially lower. Dummy coefficients for region and year effects are statistically (jointly) significant. From the region-specific fixed effects model in Column (2), we have obtained the estimated coefficients of region fixed effects as shown in Figure 4. Also here, we see substantial 
variation in region-specific factors. In the first-differencing model (Column 5), it appears that only scale is statistically significant with the expected sign, while the other variables are not statistically significant.

Table 3: Estimation results of regional bank loan interest rates ${ }^{a}$

\begin{tabular}{lccccc}
\hline \multirow{2}{*}{ Explanatory variables } & $\begin{array}{c}\text { Basic } \\
(\mathrm{OLS})\end{array}$ & $\begin{array}{c}\text { Fixed } \\
\text { Effects }\end{array}$ & $\begin{array}{c}\text { Fixed } \\
\text { Effects }\end{array}$ & $\begin{array}{c}\text { Fixed } \\
\text { Effects }\end{array}$ & $\begin{array}{c}\text { OLS-First } \\
\text { Differencing }\end{array}$ \\
\cline { 2 - 6 } & $(1)$ & $(2)$ & $(3)$ & $(4)$ & $(5)$ \\
\hline RISK & $0.123^{* * *}$ & 0.039 & $0.055^{* * *}$ & 0.011 & 0.026 \\
COST & $(0.03)$ & $(0.02)$ & $(0.02)$ & $(0.02)$ & $(0.02)$ \\
& -0.013 & 0.005 & $0.023^{*}$ & -0.011 & 0.015 \\
SCALE & $(0.02)$ & $(0.02)$ & $(0.01)$ & $(0.02)$ & $(0.02)$ \\
& $-0.074^{* * *}$ & $-0.356^{* * *}$ & 0.001 & $0.123^{* *}$ & $-0.118^{*}$ \\
INTERCEPT & $(0.02)$ & $(0.04)$ & $(0.01)$ & $(0.06)$ & $(0.06)$ \\
& $22.735^{* * * *}$ & $50.660^{* * * *}$ & $12.900^{* * * *}$ & 2.011 & $0.887^{* * *}$ \\
REGION DUMMIES & $(1.67)$ & $(3.74)$ & $(1.42)$ & $(5.43)$ & $(0.16)$ \\
TIME DUMMIES & no & yes & no & yes & no \\
\hline Observations & no & no & yes & yes & yes \\
Adjusted $R^{2}$ & 234 & 234 & 234 & 234 & 208 \\
\hline
\end{tabular}

Notes: Robust (White heteroscedasticity-consistent) standard errors in parentheses. ${ }^{*}$ means statistically significant at the $10 \%$ level; ${ }^{* *}$ at the $5 \%$ level; and ${ }^{* * *}$ at the $1 \%$ level.

Comparing the estimation results between rural banks (Table 2) and regional banks (Table 3), it appears that the model is better able to explain regional variation in the rural bank's interest rate than the regional bank's interest rate. Given the structural differences between rural banks and regional banks in their market characteristics and segmentation, this need not come as a surprise. In the following, we proceed to discuss the previous estimation results in greater detail, taking the first-differencing model as our point of departure. 


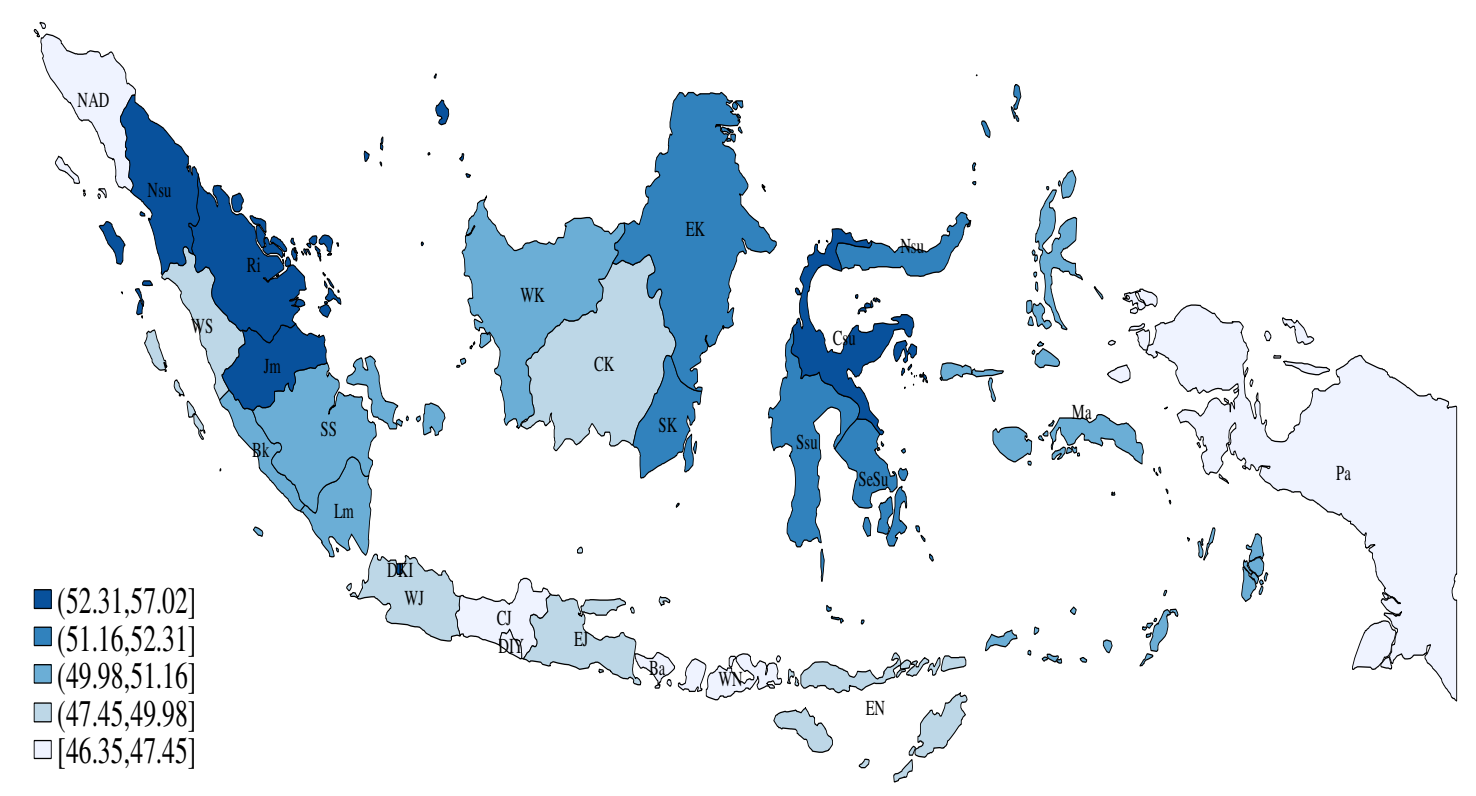

Figure 4: The estimated coefficients of region dummies from the regional bank regression.

Risk - Our results on the effect of risk on variation in regional interest rates deserve close attention. For the rural banks, changes in risk factors (problem loans) have a positive and significant effect (at the 10 per cent level) on changes in interest rates. While the risk estimate in the regional bank regression is found to be statistically non-significant, it still maintains the expected sign (positive). The low degree of significance in the model for rural banks, or even none in the model for regional banks, may partly reflect the quality of our proxy for the risk factor (see, for example, Dercon, 2002). ${ }^{17}$

Costs - The cost effect on the interest rate variation of rural banks is found to be positive and statistically significant. As predicted by the literature, administrative costs especially for microcredits are widely recognized as a prominent factor in explaining interest rate variations across borrowers. Also for regional banks the cost measure has the expected sign, but it is not statistically significant. We have also experimented with several alternative measures including the ratio of labor costs to total assets and the ratio of labor costs to deposits, but this did not

\footnotetext{
${ }^{17}$ Since most of the rural banks' customers are petty market traders, an alternative measure for the risk may therefore be more related to market-based risk. Unfortunately, we are unable to incorporate such an alternative measure due to data limitations.
} 
change the results. Furthermore, it needs to be acknowledged that regional banks in particular are more modern than rural banks, in the sense that their services are also supported by the ICT infrastructures, so their cost measure may be better captured if we would take into account the capital investment. The ratio of total operating costs to total operating incomes could thus be a better proxy. ${ }^{18}$ However, data limitations prevent us from using it.

Economies of scale - For both rural banks and regional banks we find a negative effect of scale on the loan rates indicating that larger loan volumes reduce the bank's interest rates. This finding for Indonesia is in line with findings in the literature that the scale effect exists for small banks (rural banks and regional banks).

Market concentration - The effect of market concentration on interest rates in the rural bank regression is found to be positive and statistically significant. This suggests that, ceteris paribus, a more concentrated credit market that is associated with less competitive behavior will experience higher interest rates. This result is in line with, for example, a study by Jappelli (1987) on Italy which also finds that there are significant interest rate differentials between Northern and Southern Italian banks. He further emphasizes that these differences cannot be fully explained by taking into account differences in risk or the cost structure of banks. Instead, he concludes that the difference is due to the higher concentration of banks in the Southern part of Italy.

Considering that there may be a reverse causality relationship primarily between bank loan interest rates and loan size per bank unit (SCALE), or with other variables within the estimated model, as suggested by theory, it is appropriate to use an instrumental-variables (IV) estimation rather than OLS. ${ }^{19}$ Accordingly, in order to overcome the possible correlation problem between

\footnotetext{
${ }^{18}$ This alternative proxy is also relevant, given that regional banks tend to pay "bonuses" to their local stakeholders in order to maintain their prime customers' loyalties (see also Ridhwan, 2011). This type of expense is not captured in our proxy.

${ }^{19}$ Finding an appropriate instrument is admittedly difficult. We follow common practice (e.g., Deidda and Fattouh, 2005), to use a wide array of existing instruments, viz. the lagged values of the non-exogenous regressors and of the endogenous variable (up to two periods), scale in levels, log of the number of inhabitants in each province, and GRP size (in logs) for the estimation. The use of lagged regressors as instruments was first proposed by Anderson and Hsiao (1981) in the context of dynamic panel models and was expanded upon by Arellano and Bond (1991). All other right-hand-side explanatory variables are assumed to be exogenous, and are instrumented with their own value. For simplicity, an intercept, time dummies, and individual-invariant instruments that can be used only once, were not included (Ziliak, 1997).
} 
the independent variable and error term, we utilize the two-stage least squares (2SLS) and the two-step generalized method of moment (GMM) estimator to estimate equation (8) in firstdifferences. The results are shown in Table 4. The results for the IV regressions are by and large comparable to previous results. In the rural bank regression, costs, scale and market concentration are statistically significant and have the expected sign. Similarly cost factors and economies of scale are still statistically significant and have the expected sign in regional bank regression. ${ }^{20}$

Table 4: First-differences model using Instrumental Variables

\begin{tabular}{lcccc}
\hline \multirow{2}{*}{ Explanatory Variables } & \multicolumn{2}{c}{ Rural bank interest rate } & \multicolumn{2}{c}{ Regional bank interest rate } \\
\cline { 2 - 5 } & 2SLS & GMM & 2 SLS & GMM \\
\cline { 2 - 5 } & $(1)$ & $(2)$ & $(3)$ & $(4)$ \\
\hline RISK & 0.036 & 0.054 & 0.007 & 0.008 \\
& $(0.06)$ & $(0.04)$ & $(0.02)$ & $(0.01)$ \\
COST & 0.021 & $0.164^{*}$ & $0.041^{*}$ & $0.045^{* *}$ \\
& $(0.05)$ & $(0.09)$ & $(0.02)$ & $(0.02)$ \\
SCALE & $-0.089^{* * *}$ & $-0.089^{* * *}$ & $-0.478^{* * *}$ & $-0.478^{* * *}$ \\
& $(0.03)$ & $(0.03)$ & $(0.09)$ & $(0.09)$ \\
CONCENTRATION & $3.880^{* *}$ & $3.960^{* *}$ & & \\
& $(1.49)$ & $(1.70)$ & & 182 \\
\hline Observations & 182 & 182 & 182 & \\
\hline
\end{tabular}

Notes: Robust (White heteroscedasticity-consistent) standard errors in parentheses. ${ }^{*}$ means statistically significant at the $10 \%$ level; ${ }^{* *}$ at the $5 \%$ level; and ${ }^{* * *}$ at the $1 \%$ level.

\section{Conclusions}

The main aim of this paper was to examine whether regional loan markets in Indonesia are geographically segmented. The main hypothesis is that if bank loan interest rates vary across regions, controlling for relevant spatially varying determinants of interest rates, then markets are not perfectly integrated. In so doing, we derive a simple theoretical model of loan pricing. Using

\footnotetext{
${ }^{20} \mathrm{We}$ also perform tests to determine whether endogenous regressors in the model are in fact exogenous. After 2SLS and the two-step GMM estimation with an unadjusted VCE, the Durbin-Wu-Hausman statistics are reported. In all cases, the test statistics do not reject the null hypotheses that the instruments are exogenous. In addition, the Sargan test does not reject the null-hypothesis of a valid specification. Further details are available upon request.
} 
the most recent data of local credit markets from 26 provinces of Indonesia for the period of 2000-2008, we estimated the model using a panel data approach.

In the rural bank regression, after controlling for region- and time-specific fixed effects, we find that cost-related factors, economies of scale and market concentration are jointly able to explain regional variations in interest rates. Further, in the first-differencing model, we find that changes in risk, cost, scale and concentration are jointly able to explain changes in rural bank interest rates. In the regional bank regression, after controlling for region and time-specific fixed effects, we find that only the scale variable is statistically significant and has the expected sign in explaining regional differences in interest rates. In the first-differencing model, only the change in scale is statistically significant in explaining changes in regional banks' interest rates. In general, our findings tend to be robust for different specifications and estimators.

These empirical results have the following implications. First, there are substantial interest rate differentials across regions both in rural banks and regional banks. Second, after controlling risk, cost, scale and concentration, especially in the regional fixed effects model, we found that unobserved differences in regional credit markets remain important in regional interest rate differentials. This evidence therefore suggests that the local credit markets tend to be geographically segmented. ${ }^{21}$

\section{References}

Altunbaş, Y., Gardener, E.P.M. and Molyneux, P., Moore, B., (2001). Efficiency in European banking. European Economic Review. 45(10): 1931-1955.

Anderson, T.W. and Hsiao, C. (1981). Estimation of dynamic models with error components. Journal of the American Statistical Association, 76(375): 598-606.

Arellano, M. and Bond, S. (1991). Some tests of specification for panel data: Monte Carlo evidence and an application to employment equations. Review of Economic Studies, 58(2): 277-297.

Aspinwall, R.C. (1970). Market structure and commercial bank mortgage interest rates. Southern Economic Journal, 36(4): 376-384.

Baltagi, B.H. (2005). Econometric Analysis of Panel Data, 3rd edn. Chichester, Wiley.

Bank Indonesia. (2005). Results of Study of Micro, Small and Medium Businesses (MSMEs) Profile. Jakarta: Bank Indonesia.

Barajas, A., Steiner, R.and Salazar, N. (1999). Interest spreads in banking in Colombia, 1974-96. IMF Staff Papers, 46(2): 196-224.

\footnotetext{
${ }^{21}$ Since local financial markets are not fully integrated, some studies further underline the importance of local financial development for local economic activity (see, e.g., Samolyk, 1994; Neely and Wheelock, 1997; Jayaratne and Strahan, 1996; Guiso et al., 2004).
} 
Barro, R.J., Mankiw, N.G. and Sala-i-Martin, X. (1995). Capital mobility in neoclassical models of growth. American Economic Review, 85: 103-115.

Bel, G. and Fageda, X. (2008). Getting there fast: Globalization, intercontinental flights and location of headquarters. Journal of Economic Geography, 8(4): 471- 495.

Bell, F.W. and Murphy, N.B. (1968). Economies of scale and division of labor in commercial banking. Southern Economic Journal, 35(2): 131-39.

Benston, G.J. (1965). Branch banking and economies of scale. Journal of Finance, 20(2): 312331.

Benston, G.J. (1972). Economies of scale of financial institutions. Journal of Money, Credit and Banking, 4(2): 312-341.

Banerjee, A.V. and Duflo, E. (2010). Giving credit where it is due. Journal of Economic Perspectives, 24(3): 61-79.

Berger, A.N. and Udell, G.F. (1995). Relationship lending and lines of credit in small firm finance. Journal of Business, 68(3): 351-381.

Berger, A.N. and Humphrey D.B. (1997). Efficiency of financial institutions: International survey and directions for future research. European Journal of Operational Research, 98(2): 175212.

Berger, A., Miller, N., Petersen, M., Rajan, R. and Stein, J. (2005). Does function follow organizational form? Evidence from the lending practices of large and small banks. National Bureau of Economic Research Working Paper no. 8752.

Berger, A.N. and Udell, G.F. (2002). Small business credit availability and relationship lending: The importance of bank organisational structure. Economic Journal, 112-477: F32-F53.

Bester, H. (1987). The role of collateral in credit markets with imperfect information. European Economic Review, 31(4): 887-899.

Bikker, J.A. and Haaf, K. (2002a). Measures of competition and concentration in the banking industry: A review of the literature. Economic and Financial Modelling, 9(2): 53-98.

Bikker, J.A. and Haaf, K. (2002b). Competition, concentration and their relationship: An empirical analysis of the banking industry. Journal of Banking and Finance, 26(11): 21912214.

Black, S.E. and Strahan, P.E. (2002). Entrepreneurship and bank credit availability. Journal of Finance, 57(6): 2807-2833.

Claeys, P., Moreno, R. and Suriñach, J. (2008). Fiscal policy and interest rates: the role of financial and economic integration. University of Barcelona - IREA Working Papers 200810.

Cole, R.A., Goldberg, L.G. and White, L.J. (2004). Cookie cutter vs. character: The micro structure of small business lending by large and small banks. Journal of Financial and Quantitative Analysis, 39(2), 227-251.

Corvoisier, S. and Gropp, R. (2002). Bank concentration and retail interest rates. Journal of Banking and Finance, 26(11): 2155-2189.

D’Amico, N., Parigi, N., and Trifilidis, M. (1990). I tassi d'interesse e la rischiosita degli impieghi bancari. In: Banca d'Italia, Il Sistema Finanziario nel Mezzogiorno. Roma: Banca d'Italia.

Diamond, D.W. (1984). Financial intermediation and delegated monitoring. Review of Economic Studies, 51(3): 393-414

Duranton, G. and Puga, D. (2005). From sectoral to functional urban specialisation. Journal of Urban Economics, 57(2): 343-370.

Deelchand, T. and Padgett, C. (2009). Size and Scale Economies in Japanese Cooperative Banking. University of Reading - ICMA Centre Working Paper. 
Degryse, H. and Ongena, S. (2005). Distance, lending relationships, and competition. Journal of Finance, 40: 231-266.

Deidda, L. and Fattouh, B. (2005). Concentration in the banking industry and economic growth. Macroeconomic Dynamics, 9(2): 198-219.

Dercon, S. (2002). Income risk, coping strategies, and safety nets. World Bank Research Observer, 17(2): 141-166.

Dow, S.C. and Rodriguez-Fuentes, C.J. (1997). Regional finance: A survey. Regional Studies, 31: 903-920.

Faini, R., Galli, G. and Giannini, C. (1993). Finance and development: The case of Southern Italy. In: Giovannini, A. (ed.), Finance and Development: Issues and Experiences. London: Centre for Economic Policy and Research.

Fishkind, H.H. (1977). The regional impact of monetary policy: An economic simulation study of Indiana (1958-1973). Journal of Regional Science, 17: 77-88.

Freixas, X. and Rochet, J.C. (2008). Microeconomics of Banking, $2^{\text {nd }}$ edn. Cambridge: MIT Press.

Glaeser, E. (2005). Urban colossus: Why is New York America's largest city? National Bureau of Economic Research Working Paper no. 11398.

Greenwald, B.C., Levinson, A. and Stiglitz, J.E. (1993). Capital market imperfections and regional economic development. In: Giovannini, A. (ed.), Finance and Development: Issues and Experiences. Cambirdge: Cambridge University Press.

Guiso, L., Sapienza, P. and Zingales, L. (2004). Does local financial development matter? Quarterly Journal of Economics, 119 (3): 929-969.

Hauswald, R. and Marquez, R. (2006). Competition and strategic information acquisition in credit markets. Review of Financial Studies, 19(3): 967-1000.

Jappelli, T. (1987). The estimation of the degree of oligopoly of the Italian banking sector, Studi Economici, 31, 91-105.

Jayaratne, J. and Strahan, P.E. (1996). The finance-growth nexus: evidence from bank branch deregulation. Quarterly Journal of Economics, 111(3): 639-670.

Johnston, D. and Morduch, J. (2008). The Unbanked. World Bank Economic Review, 22(3): 517537.

Jimenez, G., Salas, V. and Saurina, J. (2009). Organizational distance and use of collateral for business loans. Journal of Banking and Finance, 33(2): 234-243.

Kano, M. and Tsutsui, Y. (2003). Geographical segmentation in Japanese bank loan markets. Regional Science and Urban Economics, 33(2): 157-174.

Krugman, P. (1991). Increasing returns and economic geography. Journal of Political Economy, 99: 483-499.

Maudos, J. and De Guevara, J.F. (2004). Factors explaining the interest margin in the banking sectors of the European Union. Journal of Banking \& Finance, 28(9): 2259-2281.

McKillop, D.G. and Hutchinson, R.W. (1990). Regional Financial Sectors in the British Isles. England: Avebury.

McCann, P. (2001). Urban and Regional Economics. Oxford: Oxford University Press.

Myrdal, G. (1957). Economic Theory and Underdeveloped Regions. London: Duckworth.

Neely, M.C. and Wheelock, D.C. (1997). Why does bank performance vary across states? Federal Reserve Bank of St. Louis Working Paper no. 79.

Petersen, M., and Rajan, R.G. (1994). The benefits of lending relationships. Journal of Finance 49: 3-37. 
Petersen, M., and Rajan, R.G. (1995). The effect of credit market competition on firm-creditor relationships. Quarterly Journal of Economics, 110: 407-443.

Petersen, M.A. and Rajan, R. (2002). Does distance still matter? The information revolution in small business lending. Journal of Finance, 57(6): 2533-2570.

Pollard, J.S. (2003). Small firm finance and economic geography. Journal of Economic Geography, 3(4): 429-452.

Ridhwan, M.M. (2011). Regional Dimensions of Monetary Policy in Indonesia. Tinbergen Institute Research Series no. 499. Amsterdam: Rozenberg Publishers.

Rodriguez-Fuentes, C.J. (2005). Regional Monetary Policy. London: Routledge.

Samolyk, K.A. (1994). Banking conditions and regional economic performance: Evidence of a regional credit channel. Journal of Monetary Economics, 34: 259-278.

Simper, R. (1999). Economies of scale in the Italian saving bank industry. Applied Financial Economics, 9(1): 11-19.

Stiglitz, J.E. and Weiss, A. (1981). Credit rationing in markets with imperfect information. American Economic Review, 71: 393-410.

Sunarto, H. (2007). Understanding the Role of Bank Relationships, Relationship Marketing, and Organizational Learning in the Performance of People's Credit Bank: Evidence From Surveys and Case Studies of Bank Perkreditan Rakyat and Clients in Central Java, Indonesia. Tinbergen Institute Research Series no. 404. Amsterdam, Rozenberg Publishers.

Uchida, H., Udell, G.F. and Watanabe, W. (2008). Bank size and lending relationships in Japan. Journal of the Japanese and International Economies, 22(2): 242-267.

Venables, A.J. (2005). Spatial disparities in developing countries: Cities, regions, and international trade. Journal of Economic Geography, 5(1): 3-21.

Venables, A.J. (2010). Economic geography and African development. Papers in Regional Science, 89 (3): 469-483.

Wooldridge, J.M. (2002). Econometric Analysis of Cross Section and Panel Data. Cambridge: MIT Press.

World Bank. (2009). Improving access to financial services in Indonesia. World Bank Working Paper no. 52032 v1.

World Bank (2007). Indonesia - Public expenditure and financial accountability: Public financial management performance report and performance indicators. World Bank Working Paper no. 42098.

Ziliak, J.P. (1997). Efficient estimation with panel data when instruments are predetermined: An empirical comparison of moment-condition estimators. Journal of Business and Economic Statistics, 15(4): 419-431. 